\title{
Bolivia and Social Development: A Historical Study 1928-2015
}

\author{
Dante Ayaviri Nina ${ }^{1,2}$, Guido Fuentes Sotomayor ${ }^{2} \&$ Gabith Quispe Fernandez ${ }^{1,2}$ \\ ${ }^{1}$ Facultad de Ciencias Políticas y Administrativas, Universidad Nacional de Chimborazo, Ecuador \\ ${ }^{2}$ Universidad Técnica de Oruro, Bolivia \\ Correspondence: Dante Ayaviri Nina, Universidad Nacional de Chimborazo, Ecuador. Tel: 593-9-6937-7165. \\ E-mail: dayaviri@unach.edu.ec
}

Received: March 1, 2019

Accepted: April 4, 2019

Online Published: May 30, 2019

doi:10.5539/jsd.v12n3p193

URL: https://doi.org/10.5539/jsd.v12n3p193

\begin{abstract}
This research aims to identify the most important milestones about the design and implementation of Development Plans for the 1928 - 2015 period, considering theories and models used for defining and planning Bolivia's social development. Methodology used for this end bases on review and analysis of literature, historical reports, development models and public policies. There are contradictions between strategies and mid/long term plans, noting that social development was not considered a priority by many governments, although used as a platform in search of power spaces. This assertion is grounded by the fact that throughout the period of analysis, Bolivia implemented a set of plans and strategies; however, most strategic documents failed to territorialize designed policies, not incorporating social development explicitly.
\end{abstract}

Keywords: development models, social development, plans, strategies

\section{Introduction}

Bolivia adopted a planning system around 1928, with a series of plans and strategies, developed and implemented throughout these years; each document became a development management tool. Historically, general planning processes in Bolivia are comprised by two stages: pre-democratic stage and democratic stage, the first from 1928 to 1985, and the second from 1982 to 2015. Planning started with Kemmeer mission and corresponds to the period of the Republic 1920-2009 (Mesa, 2016). In 2009, the new Political Constitution of the State is written, entitled as the Plurinational State of Bolivia; to specify the history in the elaboration of the plans and/or strategies, we defined the following stages: 1928 - 1942 period, strongly influenced by USA through plans or strategies developed - specifically - to address mining development and organize the administrative apparatus. The second stage 1942 - 1952, was influenced by the theory of Keynesianism, promoting private investment, public investment, highway road integration, exploitation of raw materials, and others. The third stage goes from 1952 - 1984, and it is characterized by a business model for the management of the economy. The fourth stage was from 1984 - 2006, with the consolidation and hegemony of the neoliberal model and the free market. Finally, the fifth stage goes from 2006 to date, under the government of President Morales, with the building of a hybrid development model.

In each of these stages, plans and strategies were designed aiming to solve different problems - ranging from the expansion of the internal market through production and productivity, productive transformation, exports, road integration, improvement and industrialization of agriculture, migration, monetary stabilization, privatization and nationalizations, all which occurred last decade. These problems generated other problems, not resolved, though, as in the case of the social problems that affect population wellbeing. Although planning actions were conducted in Bolivia - through collaboration with international organizations, these plans did not meet the reality and context of the country (Lara, 1991; Shortall, 2004; Cortés, 2009, Ruiz, 2013), for example, social issues, arising in spite of having programs aimed to improve sectoral conditions, where reality shows different scenarios. Possibly, these plans are oversized or too superficial, or mainly related to lack of resources or simply lack of political will (Jeffrey, 1997; Shortall and Shucksmith, 2001; Chang, 2002; Mercedes Di Virgilio, 2006). Whatever the case, the truth is that these documents, when not implemented, diminished the few possibilities of meeting social needs and demands; on the contrary, if implemented, result into risks and - due to weak economic growth - may hinder social proposals implementation. Surely, much has been written about planning, from different perspectives and in some cases, studies requested by certain organizations result following - in general 
- the same trend: to improve the living conditions of its inhabitants.

Bolivia considered planning as a basis to guide its economic and social development, under the slogan of market spontaneity and planning of democratic centralism, and others. However, the same story shows that neither market systems nor planning of democratic centralism were able to achieve wellbeing. However, little has been written about their evaluation and impacts since 1928. Consequently, it is necessary to ask whether, plans and strategies managed to improve the socioeconomic situation of inhabitants in the different periods of the history of the country, were these the most appropriate to solve social development related issues and was their implementation possible? Bolivia, throughout this period has had democratic and undemocratic governments, private and public institutions that in one way or another have influenced in policies design. Therefore, it can be affirmed that plans and programs implementation - in this period - were influenced by the type of government, context and adopted development model.

Social development policy constitutes the basic instrument through which the State fulfils its role to support population well-being and improve their living conditions (Repetto, 1994, Røpke, 1994; Molins, 1998, Stiglitz, 2014, Cairós, 2015). In this sense, the following questions arise for Bolivia's context: What are the assumptions, factors and elements on which the different social development theories and models were developed and constructed? What is the historical relationship of social development theories and models and how are they related to the historical development process? What were the theories, models, approaches and programs, at the time of the preparation, design and implementation of social development plans and strategies? What factors hindered the compliance of plans and programs compared to the theoretical design? Under what social, economic, and political conditions were plans and strategies elaborated?

In this context, the objective of the research at hand is to identify plans and strategies developed and/or designed in Bolivia from 1928 to 2015, thus, analyse their implementation and operation and identify elements that contribute to social development. This based on the theoretical analysis of development models used in Bolivia, determining the application periods of development plans and strategies.

\section{Theoretical Aspects and Considerations}

\subsection{What Is Development?}

Definitions on development are diverse, understanding that it is a concept that changes according to phenomena, historical moments, and predominant social values of a given period of time (OECD, 1993, Vázquez Barquero, 1995, Naredo, 1996, Aghon et al., 2011; Bettencourt and Kaur, 2011). In this line, De Mattos (2000) defines development as a two-fold upward movement, on the one hand, the most developed societies and, on the other, the least developed.

Development or underdevelopment is understood as a set of goods and practices related to technology, productivity, influx, and greater distance from survival threshold (Gunder, 1967; Bettencourt, 2008). Consequently, whatever the concept adopted for development, there is an implicit comparative perspective, before and after, one country against another, this group of countries compared to this other one. Therefore, development concept includes the ideas of way to go.

In this line, the definition by Obregon (2007) indicates that, in almost all its uses, development implies a change or progress. The word development also evokes natural metaphors related to organic growth and evolution, but if used as a verb, "to develop" refers to activities needed to achieve expected changes; whereas when used as an adjective, "developed" is inherently a judgment, since it involves a standard used to compare things.

\subsection{What Is Social Development?}

Amin (1973) states that it is a process of promoting people's wellbeing together with an economic development dynamic process. Development economics theorists, before the 70 s, distrusted the incorporation of subjective information for the analysis of economic development, but mainly for social development. However, currently authors like Gil (1987), Alburquerque, (2004), Obregón (2007), give priority to the incorporation of subjective variables for development analysis, such as well-being or quality of life, this means that, some theorists put economic development before social development, that is, first economic growth through GDP, and later, health, education, wellbeing, and basic services variables. Another line of thought puts social development before economic development, that is, health, education, wellbeing, freedom, and others, having impact on economic development (UNDP, 2006).

For Sen (1998), development is conceived as an expansion process of real freedoms enjoyed by individuals. This definition serves as basis for strengthening the human development concept, as a joint construction that complements social development in a local context (Albuquerque, 2002). Human development refers to the 
creation of an environment where people can unfold their full potential and have a productive and creative life, according to their interests and needs (Las Heras Pinilla, 2001, Mora, 2010). Under these considerations, economic growth is a necessary condition, but not sufficient to achieve social development.

\subsection{Development Economics}

The theory of development economics is based on the pillars of economic thought, stating that this is a sub-discipline of economic science, born at the end and beginning of the Second World War (Berry and Stewart, Ray, 2002, Azqueta and Sotelsek, 2007). Authors as Hidalgo (1996), Jiménez (2017) make the following classification: theory of modernization, structuralist theory of development, neo-Marxist theory of development, neoliberal theory of development, alternative theories of development. While this classification encompasses economic development, in particular, it also allows addressing social development issues. It is considered to be a sub-discipline of science that deals with the study of economies of less developed countries, considering their conditions, characteristics and economic development policies (De Mattos, 2000; Las Heras Pinilla, 2001; Mora, 2010), that is, development itself, embedding development in health, education, citizen security, and basic services areas (Las Heras Pinilla, 2001). It also takes into account society demands within the economic dimension, focusing on mid and long-term planning (Blanco, 2013); including the search for social development and the promotion of society wellbeing together with an economic development dynamic process.

\subsection{Development and Modernization of the State}

Modernization is defined as the change and transformation process of society and its territorial context, experiencing changes in their lifestyles and productive processes (Pieterse, 1998, Hernández, 2004). It is also understood as the "gradual replication of a status reached by benchmark countries or regions, that is, the geo-economic spaces that supposedly went through a historical break -the Industrial Revolution-, moment from which industrial growth became a natural condition and fundamental objective of the functioning of society" (Hidalgo, 1996, p.122).

The neo-Marxist theory of development emerges as an alternative to the theory of modernization because of the excessive dogmatism used to implement it. This theory begins with Baran (1959) through his work "the political economy of growth", stating that economic underdevelopment is a process characterized by the continuous extraction of surplus generated in the periphery by developed capitalist economies, consequently, economically underdeveloped countries are characterized by low income and low rates of capital accumulation. Thus, full economic development can only occur through a political and economic change in its structures. With Baran's (1959) theoretical background, and the contributions Baran and Sweezy (1966), Magdoff, (1969), Amin (1973), the theory of imperialism is born, representing modern capitalism through corporations or multinationals that dispute the control of the market through competitions.

It is Dos Santos (2002), who enriches the theory - by stating the impossibility of development in dependent-countries under a capitalist system, as it does not generate development; on the contrary, it generates underdevelopment by dismantling its productive structure and adapting their economies to those of developed countries, governed by the free market, becoming underdevelopment a usable and functional element to the interests of the developed countries - under the world capitalist system, making the search for social development impossible. During the seventies, Amin (1973) presents the disconnection, a way to separate from the system.

The neoliberal theory of development lies on the defence of market effectiveness as a mechanism for optimal allocation of resources, criticizing public intervention in economic activities, and insisting on the advantages of full participation in international trading, criticizing as well the industrialization model through import substitution, implying restrictions on imports, Bustelo, 1992; Huber and Stephens, 2001). Bolivia could be identified with this theory by considering strategic plans developed in the period of 1985-2006 for structural adjustment, where the ten most important companies were privatized; while for the fifties and sixties, it is not possible to find theoretical proposals for social development, understanding that mining was the main economic activity.

The alternative theories of development, opposed to the approach described, consider development as an effect of economic growth. However, in the seventies, the emergence of new notions of development focusing on basic needs satisfaction arise. This fact earmarks the most important change in the history of Development Economics, since it is a radically different approach to all previous ones (Hidalgo, 1996, Maioni, 1998; Reyes, 2001). This common ground and new ways of government and action result from planned economies (Robinson and Bofill, 1979; Ameringer, 1992). Being this the letter of introduction for the Bolivian case, where Supreme Decree 21060 (1985) was the expression of a public policy aimed at controlling all those elements producing inflation, 
resulting into the rupture of previous ways of planning and giving birth to State modernization.

Later, the theory of human development arises, modifying the concept of development based on production and capital accumulation, by one based on human and social capabilities (Delval, 1994, UNDP, 2001, Uribe, 2004; Ferreira and Walton, 2004; Huber et al., 2006; Obregón, 2007). The concept of human development isolates development level GDP (Gross Domestic Product) as the main indicator, questioning - as well - the assumption that accumulation of physical capital is the mean to achieve development, that is, investment in industrial facilities and equipment.

\section{Results}

\subsection{Development}

As of 1928 (approximately), Bolivia adopts planning through the implementation of plans or strategies; however, achieved social development- apparently - is not related to them, on the contrary it responds to other types of actions or adopted measures, neglecting the implementation of a continuous and clear path for social development as State policy. Throughout history, plans and strategies were changed, discarded, modified or ignored when implemented, leaving aside budgetary allocation, prioritizing and conditioning international cooperation lines, taking advantage of social sector institutional weakness or the excessive focusing on population (Morales, 2006). Each of these plans were used as management tools to foster sectoral development; however, when drafting them, some sectors are more privileged than others. This is evident when seeing how they are named (economic development plan, reconstruction plan, stabilization program, indicative global plan, etc.), responding in many cases to the historical moment, and to the focus and the characteristics of the government in office.

In the period of analysis, the presence of two models of development is predominantly visible, used in literary production for analysing social development by considering needs satisfaction and demand, based on different development paradigms: social development, human development, sustainable human development, sustainable development, development with equity, and others. Therefore, it is noted that these theories are not related to proposed strategies or plans. Although planning in Bolivia has been done with the support of international organizations, plans at some point did not answer to the reality of the country, in social aspects, despite of their social orientation. Other factors also influenced implementation and results achievement, such as budget, technical issues and agendas.

\subsection{Background in Bolivia}

Bolivia was born to independent life with approximately one million inhabitants, of which more than $80 \%$ were indigenous people and just over $90 \%$ lived in the rural area, carrying-out having agriculture, raising of small livestock and handcrafting activities, most of them for self-consumption. Bibliographical references - as stated by Carranza (1982), Tapia (2002) - show that the first attempt in Bolivia to introduce planning for economic development begins in 1928, under the government of Dr. Hernando Siles, with the Kemmerer Mission, resulting into the creation of regulations for public management organization (finances and public spending) and the creation of the Comptroller General of the Republic in force until today. Until the national revolution (1952), governments in office put their efforts to stabilizing the economy by implementing different policies - which in many cases failed or promoted the consolidation of the export model (GTZ, 2009, Mesa, 2014), also worth noting that Kemmerer Plan did not incorporate social development strategies.

Starting 1952, the state capitalism model began, and with it, the nationalization of mining, Agrarian Reform, sectors identification and economy spatial integration aiming to broaden the country's economic base. However, in the period of 1952-1956, Bolivian economy conditions worsened. During the first half, 1951, Keeleyside (Note 1) report is presented, becoming relevant after the assessment of the country's economic and social situation and implementation measures; however, this plan could not be implemented because of country's social upheaval. This is the first document giving specific reference to the social development of Bolivia. It is from 1955 that the drafting of different development plans begins, incorporating the social development component, although, illustrative in some cases.

The plan called "Plan Guevara Arce, 1955" from the national revolution was launched with great expectations, having the following core goals: to present to the Government of the United States the real scenario of the country's economy, requesting food aid and capital goods. It mentioned that one factor for low productivity was related to weak productive activities and diversification. The plan included the following projects: 
Table 1. Plan Guevara Arce, projects identified by sector 1955

\begin{tabular}{lc}
\hline \multicolumn{1}{c}{ Sectors } & Number of Projects \\
\hline Mining & 5 \\
Oil & 4 \\
Hydroelectric power & 3 \\
Development of the Villamontes Area & 2 \\
Beni-Reyes Cattle Project & 2 \\
Development of the valleys of Cochabamba, Tarija and Potosí and the highlands. & 7 \\
Roads, Transportation and communication & 13 \\
Industrial development & 9 \\
\hline
\end{tabular}

Source: Own elaboration based on BCB database (2010).

As shown, some economic sectors were prioritized. The most important sector for the number of projects is communication, construction of roads, and transport improvement, leaving aside the prioritization of social projects; however, implicitly, they should be part of each prioritized sectors. The same year, the government in office turned to the Economic Commission for Latin America ECLAC, for the design of a new plan known as the "Bolivian Study" carried-out by the ECLAC Secretariat, focused on situational planning. This document results being the most formal document about social and economic situation of the country.

In 1960, the "Government Program for Immediate Investments and Priorities" was published, prepared by the National Planning Board, created in 1953 under the name of the National Coordination and Planning Commission. According to its strategic lines, the following sectoral projects were prioritized: mining, oil, agriculture and food industry, transport, electric power and social improvement. This Program considers a social component, ranking in the sixth position though. However, one obstacle for its implementation was related to the lack of completed projects. One strategic document, after the National Revolution, is the so-called National Economic and Social Development Plan 1962-1971, known as the "Ten-Year Plan" developed by an advisory group of ECLAC/FAO/TAO at request of the then National Board of Planning. The Ten Year Plan proposed "defining - comprehensively - the magnitude and orientation of efforts to be done during the next years to break the stagnation of the national economy, overcome a good portion of poverty conditions most population lives in, productivity increase and opening of employment opportunities ..." (Loza, 2015, p.2), goals of this document were of a social nature and sought to improve the living conditions of the population, but with priority for the vulnerable population. The plan intended to cover, for example, the food deficit, school attendance for the entire urban population and $80 \%$ of the rural area; for public health, the strategy was to double current expenditures over the next five years, thus, reducing mortality and morbidity rates, eradicating malaria and smallpox, providing housing and basic urban and rural services; potable water, sewage system.

At the end of the first five period, this document was subject of different analyzes and criticisms, in the sense that the plan was too social and not so much economic sided, and that established goals, would not be achieved, for example, poverty reduction. Plans and programs developed to this period were earmarked by the objectives of 1952 revolution, under the statist model, without this meaning that the achievement of such goals would improve the situation of the population. In fact, many of the objectives were not achieved.

From 1962 to 1971, several plans that considered social policies were elaborated and developed, for example, the National Plan for Rural Development outlined the incorporation of $89 \%$ of the population into the social life of the country, seeking the improvement of peasants quality of life, turning them into producers and sellers of basic food for the urban population, an objective that was not fulfilled; on the contrary, economy generated by these sectors was of subsistence. Next Table shows the national economy sectors. 
Table 2. Objectives of the national plan for rural development, 1962-1971

\begin{tabular}{ll}
\hline Sector & Objective \\
\hline Health & $\begin{array}{l}\text { Maternal and child hygiene, environmental sanitation; control of epidemics; } \\
\text { medical care and health education. }\end{array}$ \\
Nutrition & $\begin{array}{l}\text { Increase and diversification of agricultural production, education in nutrition and } \\
\text { domestic economy. }\end{array}$ \\
Social Service & $\begin{array}{l}\text { Promote improvement of social aspects, training of social service assistants. } \\
\text { Research }\end{array}$ \\
& $\begin{array}{l}\text { Socio-economic research, national service of by-sampling research for } \\
\text { demographic and agricultural affairs for family consumption. }\end{array}$ \\
Building & Building of hospitals, health centres, schools. \\
\hline
\end{tabular}

Source: Own elaboration based on BCB historical data.

The Plan is strengthened with two biennial plans, the first one called Economic and Social Development Plan 1963-1964 and the second, with the same name for the 1965-1966 period; these two documents were prepared under the guidelines of the 10-year plan. Both plans contain a biennial plan for the agricultural sector, mining, oil, industry, energy, transportation, education, public health, public services. Undoubtedly, these plans incorporate strategies that address social and economic development and are documents that coherently describe the situation Bolivia was facing at that time, including measures that could improve the economic and social situation of the country. This is the document that stresses the fact that economic and social development should be addressed based on external loans. Possibly, Bolivia is the country with more development plans for this period, either $\mathrm{mid} /$ long term plans, with common objectives to achieve economic and social development. However, it is equally true that a large part of these documents were only used as reference or implemented to a lesser degree, either because of their drafting technical weakness or because of lack of political decisions for their implementation (Toranzo, 1998).

These Plans are followed by others, with the same objectives and with some particularities. The Plan that earmarks the incorporation of planning is the National Planning System created under the government of General Hugo Banzer Suarez (1971), establishing country economic and social development programs as fundamental regulations for plans' preparation, evaluation, and control. However, it is the Socio-economic Strategy for National Development (Bolivia 1971-1991) drawn up under the government of Adolfo Ovando (1969), which best describes the situation of the country from a technical, methodological, ideological and political point of view. Again, in this period - from 1969 to 1990 - other Plans were elaborated with technical characteristics that answer to the National Planning System and with social and economic strategies and objectives that do not differ from previous ones.

From 1985, the free market economy comes to stage again in the history of Bolivia with the enforcement of Supreme Decree 21060, with the purpose to reorganize and modernize the state and productive apparatus and incorporate social investment programs and strategies, with the purpose of reducing poverty, preserving macroeconomic stability and seek - above all - social equity. The enforcement of this decree had a high social cost from which the country does not finish recovering, earmarking the beginning of 15-year structural reform, time in which social issues are addressed based on concepts developed by modernization theorists.

During the government of Jaime Paz Zamora (1989-1993), the Plan called "National Development Strategy" was drawn up. This document emphasized poverty and social aspects as means to satisfy basic needs: employment, health, education, nutrition, basic sanitation, and others, within a context of economic stability. This plan was enforced in 1992 with a long-term prospect. However, in this period some plans and/or programs were implemented with the Social Investment Fund (FIS) and the Bolivian Social Strategy (ESB). The latter makes concrete reference to social development and sets the need for a social strategy to address development, socioeconomic indicators, and highlights the need of having a social strategy as an indispensable component for the development strategy (Mesa, 2014). In 1997, under the government of Hugo Banzer Suarez, replaced by Jorge Quiroga Ramírez, the General Plan for Economic and Social Development (PGDES) 1997-2002 was designed and enforced. Bolivia XXI: Socially Solidarity Country. The development of this document is placed in the context of the National Dialogue and Fight against Poverty, incorporated in the Bolivian Strategy for Poverty Reduction. This is the Plan giving birth to the concept of social market economy, unlike the previous ones. It is 
necessary to highlight some of its objectives: decrease of urban and rural poverty, promotion of social market economy, market transparency and efficiency, human security, generation of stable employment, equitable distribution of wealth, social consensus and others; it also addressed strategic agreements for poverty reduction within the framework of HIPIC II agreement (Highly Indebted Poor Countries), supported by four pillars: opportunity, equity, dignity and institution-building.

In the governments of Carlos Mesa and Eduardo Rodríguez, the deterioration and decomposition of the free market model is present with greater clarity, although strategies theoretical bases considered a Productive Bolivia through dialogue, aimed at strengthening Poverty Reduction Strategy actions. The short period of Rodríguez Veltzé is characterized by instability, uncertainty, and the emergence of new social actors, politicians and leaders. From 2005, with the government of Evo Morales, Bolivia returns to the nationalist statism, with a program that tries to modify the socio-economic situation of the country through measures ranging from the modification of the State Political Constitution (2009), where the country's name is changed to the Plurinational State of Bolivia, creating social measures through the redistribution of income via cash-bonuses and subsidies, also used in previous governments. The National Development Plan 2006-2011 presents a variance against the Plan design, first chapters prioritize social issues, trying to show that social development is not conditioned to economic growth.

From the second mandate of Evo Morales, the National Development Plan for a Sovereign, Productive and Democratic Bolivia to Live Well (2006-2011) was elaborated. For its implementation, the reconfiguration of the State role in economy is proposed, by changing the productive matrix, decolonization, and switching the pattern of primary export development. A new paradigm is incorporated "Living Well" based on the Andean vision (cosmovision) in substitution of sustainable development. The Objectives of Living Well aim for balanced coexistence and complementarity with equity, emphasizing state economy, community economy, mixed and private. Policies that support this paradigm are summarized in nationalization of hydrocarbons, social protection, and eradication of extreme poverty.

The National Development Plan 2010-2015 was designed for the second mandate of Evo Morales, called "Productive Plurinational Economic Model" based on the increase of natural resources production and nationalization of hydrocarbons, making possible the industrialization of hydrocarbons, minerals, food, production of medicines and textiles. Sectors prioritized by the Plan are mining, hydrocarbons, electric power, transportation, industrial production, housing, communication, water and basic sanitation, telecommunications, education, rural development, poverty eradication, tourism, health, citizen security, science and technology.

The strategic plan shows the importance of each economic sector, the presence of several sectors is due to the vision of the adopted development model. This prioritization shows the relative importance of social development, for example, water and sanitation rank in the eighth position, education in the tenth, and health fifteenth. However, it is necessary to emphasize that, for example, poverty eradication policies have a lot to do with social programs for wealth redistribution trough Juana Azurduy de Padilla Bonus, Juancito Pinto Bonus, and social assistance programs for the areas of health and education.

The Economic and Social Development Plan 2016-2020, within a framework of comprehensive development to Live Well, aims to reduce extreme poverty from $17.3 \%$ to $9.5 \%$, within the framework of the Patriotic Agenda postulates, moderate poverty, from $39.3 \%$ to $24 \%$, reduction of the chronic malnutrition rate in children from $18.1 \%$, in 2012 , to $9 \%$ until 2020 , undernourished population reduction from $21.3 \%$, in 2012 , to $10 \%$ in 2020 . The Patriotic Agenda is a long-term strategic document (2025) that contemplates and systematizes policies, objectives and goals drawn from the year 2006 on. It is supported by thirteen pillars, of which, the most relevant for this research are the first three: 1) eradication of extreme poverty; 2) socialization and universalization of basic services with sovereignty to Live Well; 3) health, education and sports for the comprehensive development of individuals. According to the Patriotic Agenda, poverty is conceived in Bolivia through three dimensions: material poverty, social poverty and spiritual poverty, being the first the one a priority - as stated in the agenda because in Bolivia, extreme poverty mainly lies in the material dimension and in the indigenous population, in women and children. The agenda also privileges the socialization and universalization of access to basic services, since it is considered a human right.

On the other hand, the Plan envisages guaranteeing public and free education services, as well as accessible, free, and quality health services that protect and provide health, well-being and happiness to the entire population, and contribute to the comprehensive development of individuals. This new paradigm - incorporated to Bolivia's development - under the philosophy of "Living Well", inserted in the Development Plan, has become a different answer possibility, opposed to the economic development paradigm, which mainly lies on economy growth 
measured through the GDP, GDP per capita, and others, incorporating subjective variables that promote individuals comprehensive development by meeting their needs and demands. Therefore, it matches with the human development philosophy.

\section{Conclusions}

Most plans - only for some exceptions - do not present information about advances and achievements made on social issues, leading to the conclusion that each document faces different problems in the evaluation methodology; however, reality throughout history shows something different. As for strategies and/or designed social policies, it is noted that most of them are part of another document, that is, as a section of the development plans - a weakness present throughout time. However, it possible to see that by the end of the 80 's and beginning of the 90's, sectoral plans or strategies are developed. The influence of development economy trends for the building of policies and/or social strategies provide answers to economic type problems (growth, industry, commerce).

This paper does not look for a discussion on schools or ways of planning, but rather, specify the weight of the theoretical currents of development economics in the addressing of social problems throughout the assessment phase and in the formulation of developed Plans. Bibliographic review resulted into the identification of approximately 43 strategic documents among plans, programs and/or reports from 1928 to 2015. Many of them are general documents to address economic development, with a subsequent orientation towards social development.

Although social development tries to reflect in some way - at least from a theoretical point of view - the "positive" change in individual's condition (health, education, basic services, citizen security, etc.), showing improvements in quality of life rates; it is equally true that most strategies' vision consider that social development lies on the economic development of some strategic sectors, such as mining, hydrocarbons, etc. Consequently, social development, ultimately, depends on the performance of these sectors.

Social development has its origin in the social and economic reforms implemented in the fifties, mainly. As a result, changes were made that resulted in the consolidation of social policies that had the effect of improving the quality of life of the Bolivian population.

\section{References}

Aghon, G., Alburquerque, F., \& Cortes, P. (2001). Desarrollo económico local y descentralización: Un análisis comparativo, Publicaciones de la CEPAL/GTZ, pp. 1-332.

Alburquerque, F. (2002). Desarrollo económico local, Editorial Instituto de Desarrollo Regional - Fundación universitaria, Sevilla.

Alburquerque, F. (2004). Desarrollo económico local y descentralización en América Latina. Revista de la CEPAL, (82), 157-171. https://doi.org/10.18356/5a9b65f3-es

Alfonso, J. (1987). Procesos de formulación de las Políticas de Desarrollo Local, la experiencia española. Editorial MOPU, España.

Ameringer, C. (1992). Political Parties of the Americas, 1980s to 1990s. Westport, CT and London: Greenwood Press.

Amin, S. (1973). Le développement inégale. Un essai sur les formations sociales du capitalisme périphérique. Paris Ediciones, Barcelona.

Azqueta, D., \& Sotelsek, D. (2007). La Economía del Desarrollo: una perspectiva histórica. Ekonomiaz: Revista vasca de economía, (64), 35-48.

Baran, P., \& Sweezy, P. (1966). El capital monopolista. Ensayo sobre el orden económico y social de los Estados Unidos. Ediciones Siglo XXI, Mèxico.

Berry, A., \& Stewart, F. (1999). The evolution of Development Economics and Gustav Rani's role. In en Saxonhouse, G. R., \& T. N. Srinisavan (Eds.), Development, duality and the international regime. Essays in honor of Gustav Ranis. The Univ. of Michigan Press, Michigan.

Bettencourt, L. (2008) Population modeling of the emergence and development of scientific fields. Scientometrics, (75), 495-518.

Bettencourt, L., \& Kaur, J. (2011). The evolution and structure of sustainability science. Proc Natl Acad Sci USA. https://doi.org/10.1073/pnas.1102712108

Blanco, C. (2013). La planificación del desarrollo: ¿problema económico, político o jurídico? Opinión Jurídica: 
Publicación de la Facultad de Derecho de la Universidad de Medellín, 12(24), 169-187.

Bustelo, P. (1999). Teorias contempraneas del desarrollo económico. Madid: Sintesis.

Caarós, D. (2015). El desarrollo de la política europea sobre protección social. Nueva revista española de derecho del trabajo, (180), 27-74.

Carranza, J. (1982). Proceso Histórico de la Planificación en Bolivia. GTZ, La Paz Bolivia.

Chang, H. (2002). Kicking Away the Ladder. Development Strategy in Historical Perspective. London, Anthem Pres.

Cortés, M. (2009). Cooperación local al desarrollo: experiencia en Pando, Bolivia. Almenara: revista extremeña de ciencias sociales, (1), 23-34.

De Mattos, C. (2000). Nuevas teorías del crecimiento económico: una lectura desde la perspectiva de los territorios de la periferia. Revista de Estudios Regionales, (58), 15-36. https://doi.org/10.1590/S0103-40141999000200010

Delval, J. (1994). El desarrollo humano. Editorial Siglo XXI, Madrid España.

Dos Santos, T. (2002). Teoría de la dependencia. Balance y perspectiva, México.

Ferreira, F., \& Walton, M. (2004). Inequality in Latin America: Breaking with History? Washington: The World Bank.

GTZ. (2009). Aproximaciones históricas a los procesos de planificación. Editorial Quatro Hermanos.

Gunder, F. (1967). Capitalismo y subdesarrollo en América Latina. Buenos Aires.

Hernandez, M. (2004). Modernización del Estado y crecimiento. Política exterior, 18(101), 25-31.

Hidalgo, A. (1996). Una visión retrospectiva de la economía del desarrollo. Universidad de Huelva, España.

Huber, E., \& Stephens, J. (2001). Development and Crisis of the Welfare State: Parties and Policies in Global Markets. Chicago: University of Chicago Press. https://doi.org/10.7208/chicago/9780226356495.001.0001

Huber, E., Pribble, J., \& Stephens, J. (2006). The Politics of Poverty in Latin America and the Caribbean. Presented at the annual meetings of the Latin American Studies Association. San Juan, Puerto Rico.

Jeffrey, V., Panayotou, T., \& Hartwick, J. (1997). Resource Depletion and Sustainability in Small Open Economies. Journal of Environmental Economics and Management, 33(3), $274-86$. https://doi.org/10.1006/jeem.1997.0992

Jimenez, C. (2017). Etapas del desarrollo de la economía mundial, Lecciones sobre economía mundial: introducción al desarrollo y a las relaciones económicas internacionales. UCM, España.

Lara, S. (1991). Organización, desarrollo y O.N.G.: el caso de Bolivia, Africa América Latina, cuadernos. Revista de análisis sur-norte para una cooperación solidaria, (5), 53-94.

Las Heras Pinilla, P. (2001). Desarrollo humano. Leviatán: Revista de hechos e ideas, (85-86), 21-32.

Loza, G. (LA RAZON, Edición impresa). (2015). El ideólogo del plan nacional de desarrollo. La Paz, Bolivia.

Magdoff, H. (1969). La Edad del Imperialismo: Política económica internacional de Estados Unidos. Edit. Nuestro Tiempo, México.

Maioni, A. (1998). Explaining Differences in Welfare State Development: A Comparative Study of Health Insurance in Canada and the United States. Princeton: Princeton University Press.

Mercedes Di Virgilio, M. (2006). La política social orientada al desarrollo: debates sobre su institucionalidad. Perfiles latinoamericanos: revista de la Facultad Latinoamericana de Ciencias Sociales, (28), 213-230.

Mesa, C. (2010). Historia de Bolivia. Editorial Gisbert, Bolivia.

Mesa, C. (2014). Breve historia de las políticas públicas en Bolivia, 2da edición. Editorial Gisbert y Cia. S.A.

Molins, M. (1998). Teoría de la planificación. Editorial CEP-FHE-UCV. Caracas-Venezuela.

Mora, A. (2010). Desarrollo económico y desarrollo humano. Razón y fe: Revista hispanoamericana de cultura, (1336), 127-142.

Morales, R. (2006). Hacia una nueva visión de la planificación económica en Bolivia. Cuarto Congreso de la Asociación de estudios Bolivianos. Sucre, Bolivia.

Naredo, J. (1996). La economía en evolución. Historia y perspectivas de las categorías básicas del pensamiento 
económico. Siglo XXI, Madrid.

Obregón, D. (2007). Planeación para el desarrollo humano y bases metodológicas para su instrumentación. Centro de Estudios Andaluces, Sevilla España.

Obregón, D. (2007). Tesis Doctoral: planeación para el desarrollo humano y bases metodológicas para su instrumentación. Análisis de las experiencias en Andalucía y Jalisco. Universidad Politécnica de Madrid, España.

OCDE, (1993). OCDE Core Set of Indicators for Enviromental Perormance Reviews. Paris.

Pierterse, J. N. (1998). My Paradigm or Yours? Alternative Development, PostDevelopment, Reflexive Development. Development and Change, (29), 343-373.

PNUD. (1990). Informe sobre desarrollo humano. Nueva York, USA.

PNUD. (2001). Informe sobre Desarrollo Humano 2000. Programa de las Naciones Unidas para el desarrollo, La Paz Bolivia.

PNUD. (2006). Informe sobre Desarrollo Humano 2016, Desarrollo humano para todos. New York, USA.

Ray, D. (2002). Economía del desarrollo. Antoni Bosch Editor, Barcelona.

Repetto, F. (1994). Política Social entre la democracia y el desarrollo. Nueva sociedad, (131), 132-143.

Reyes, G. (2001). Principales teorías sobre el desarrollo económico y social. Revista NOMADS, (3), 45-56.

Robinson, J., \& Bofill, M. (1979). Economía de mercado versus economía planificada. Ediciones Martínez Roca, Madrid, España.

Røpke, I. (1994). Trade, development and sustainability: A critical assessment of the "free trade dogma". Ecological Economics, 9(1), 13-22. https://doi.org/10.1016/0921-8009(94)90013-2

Ruiz, D. (2013). Las ONG's y la cooperación al desarrollo. Temas para el debate, (221), 29-30.

Sen, A. (1998). Las teorías del desarrollo a principios del siglo XXI. Banco Interamericano de Desarrollo, Washington, DC.

Shortall, S. (2004). Social or Economic Goals, Civic Inclusion or Exclusion? An Analysis of Rural Development Theory and Practice. Sociologia Ruralis, 44(1), 109-123. https://doi.org/10.1111/j.1467-9523.2004.00265.x

Shortall, S., \& Shucksmith, M. (2001). Rural development in practice: issues arising in Scotland and Northern Ireland. Community Development Journal, 36(2), 122-134. https://doi.org/10.1093/cdj/36.2.122

Stiglitz, J. (2014). La gran brecha Que hacer con las sociedades desiguales. Editorial Taurus.

Tapia, L. (2002). La producción del conocimiento local. Historia y política en la obra de Rene Zabaleta Mercado. Editorial Muela del Diablo.

Toranzo, C. (1998). Estrategias de desarrollo y procesos de planificación: memoria del seminario sobre estrategias de desarrollo y procesos de planificación. La Paz Bolivia.

Uribe, C. (2004). Desarrollo social y bienestar. Universidad Humanística, Colombia.

Vázquez Barquero, A. (1995). El desarrollo económico local en Europa. Ediciones Colegio de Economistas de Madrid, España.

\section{Note}

Note 1. Bolivia signs a cooperation agreement with the United Nations; the head of the mission was Dr. Hugt Keeleyside.

\section{Copyrights}

Copyright for this article is retained by the author(s), with first publication rights granted to the journal.

This is an open-access article distributed under the terms and conditions of the Creative Commons Attribution license (http://creativecommons.org/licenses/by/4.0/). 